\title{
REPORODUCTIVE PERFORMANCE OF OREOCHROMIS NILOTICUS THROUGH THREE SEASONS IN EARTHEN PONDS
}

\author{
Mohamed El- Sayed Farag \\ Genetics Department. Central Laboratory for Aquaculture Research. \\ Abbassa, Agricultural Research Center, Egypt.
}

Key words: reproductive performance, relative fecundity. Oreochromis niloticus, water temperature, earthen pond.

\section{ABSTRACT}

$\mathrm{R}$ eproductive performance of Oreochromis niloticus broodstock was examined in earthen ponds through three spawning seasons in Sedy Salm City. Kafer Al-Sheikh Governorate. 21 thousand females $(65-150 \mathrm{~g})$ and 10.5 thousand males $(75-200 \mathrm{~g})$ were randomly assigned to 10 ponds $\left(750 \mathrm{~m}^{2}\right)$ at a density of $600 ; 700 \&$ 800 females and $300 ; 350 \& 400$ males per pond. Fish were exposed to different levels of water temperature ranging from $20.04{ }^{\circ} \mathrm{C}$ to 36.06 ${ }^{\circ} \mathrm{C}$ during the three spawning seasons.

Oreochromis niloticus began to lay eggs at water temperature $20.06^{\circ} \mathrm{C}$. Spawning percentage increased during April; May and June were $23.82 ; 30.05$ and $20.61 \%$ at water temperature $20.04 ; 26.26$ and $34.75^{\circ} \mathrm{C}$ in three seasons respectivialy. During May, 2000, 2001 \& 2002 female gave high number of fries $/ . \mathrm{m}^{2} /$ day; $7.85 \pm 1.73$; $6.84 \pm 1.16$ and $7.85 \pm 2.03$ fries $/ \mathrm{m}^{2} /$ day, respectivialy. Also, high female relative fecundity were $1.25 \pm 0.41 ; 1.76 \pm 0.24$ and $1.3 \pm 0.34$ fries/g female body weight at three season, respectivialy. On the other

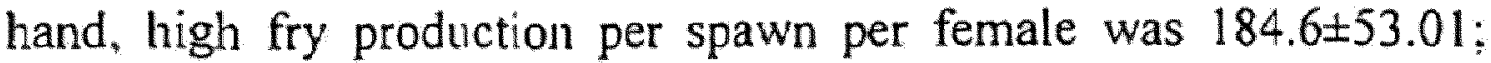
$149.26 \pm 31.87$ and $143.26 \pm 25.37$ fries / female, when water temperature was $20.04 ; 26.79$ and $26.26^{\circ} \mathrm{C}$, respectivialy.

It is evidant that the reproductive performance of Oreochromis: niloticus could be maximized by holding broodstock under natural photoperiod in water temperature above $20^{\circ} \mathrm{C}$, the optimal reproductive performance occurs through summer season during May. The optimal water temperature range was $28-31{ }^{\circ} \mathrm{C}$ and females with highest body weight started to spawn first and gave more total fries. 


\section{INTRODUCTION}

Tilapia species are very important either in natural or cultured our freshwater ecosystems. Economic importance of Tilapia is constantly increasing for their fast growth, disease resistance, different feeding habits and palatability (Dagzie, 1982). Tilapias are second to the carps in weight harvested from culture ponds (Lovshin. 1997). The Nile tilapia, Oreochromis niloticus, is the most widely cultured tilapia in the world because of its rapid growth, late age of sexual maturity and planktivorous feeding habits (Gonzalez, 1997).

In the Delta area of Egypt, spawning of Tilapia extends from April to November with a peak in early summer (El-Saby, 1951). Tilapia culture is hindered by reproductive characteristics of its main species. Excessive reproduction in culture ponds reduces the growth rate of adult fish, and reduces marketable production. The low fecundity of Tilapia can make the production of adequate numbers of fingerlings difficult. Tilapia can reproduce in concrete tanks (Badawy, 1993). Also, he reported that the number of eggs per spawn may differ among species and strains, but within species the larger the female the greater the number of fry produced.

Ovulation based on the life cycle was a reasonable means for predicting time of stripping. Hormonal induction of ovulation would seem to be a logical method for determination of egg collection; however, cichlids have responded poorly to gonadotropic therapy (Rana, 1988). On the other hand, the physiological characteristics of tilapia gametes provide an advantage in chromosome manipulation. Eggs retain high fertility for three to six hours post-immersion in water (Myers et al., 1995) and sperm remain motile in water for several hours in contrast with most fishes (Yeheskel and Avtalion, 1986).

Carriillo ef al. (1993) reported that spawning time on Sea bass (Dicentrarchus labrax) could be advanced by using a month of long days in an otherwise constant short photoperiod.

Smith (1996) reported that reproductive success and fry survival of red tilapia with genetic components from $O$. niloticus, $O$. aureus and $O$. mossambicus to pure $O$. niloticus. No significant difference was found in reproductive performance and in fry survival during sex reversal between the red tilapia and Nile tilapia. Nile tilapia females yielded 2,701 fry and red females 2,718 fry per kilogram of body weight per 13- to 19-day spawning cycle. An 
average of $80 \%$ and $77 \%$ of the Nile and red tilapia fry, respectively, survived the 14- to 28-day sex reversal period.

Abd El-Nasser et al. (200l) reported that the manipulation of photoperiod and temperature as the main factors in gonadal regulation and spawning of Clarias gariepinus became one of the means to adjust the timing of spawning to offer eggs and fry when they are demanded by fish farms.

Devlin and Nagahama (2002) found that sex determination in tish is a very flexible process with respect to evolutionary patterns observed among genera and families, and within individuals is subject to modification by external factors. These influences can affect the fate of both somatic and germ cells within the primordial gonad, and include the action of genetic, environmental (e.g. temperature), behavioural and physiological factors.

$\mathrm{Su}$ et al. (2002) reported that the genetic correlations of reproductive traits with body weight in rainbow trout at ages prior to 252 days were not significantly different from zero, while those with body weight at ages from 252 to 364 days were significantly greater than zero and increased with increasing age. The range of estimated genetic correlations between reproductive traits and body weight at ages from 252 to 364 days were: for egg size, from $0.18 \pm 0.08$ to $0.29 \pm 0.06$; for egg number, from $0.21 \pm 0.08$ to $0.32 \pm 0.06$; for egg volume, from $0.28 \pm 0.08$ to $0.45 \pm 0.06$ and for post-spawning weight, $0.25 \pm 0.11$ to $0.61 \pm 0.08 \mathrm{~g}$. As a whole, the genetic correlations between reproductive traits and body weight during the first year were favorable, allowing positive genetic improvement in both body weight and reproductive traits.

The objective of this study was to evaluate the effects of water temperature, female brood fish age and brood fish weight on the production of fries in earthen ponds through three spawning seasons.

\section{MATERIAL AND METHODS}

\section{I- Breeding systems}

Orochromis niloticus broodstock were collected from different fish farms surounding the fish hatchery and transported to 10 earthen managed ponds $\left(750 \mathrm{~m}^{2}\right)$ with improved pond design and management in Sedy Salm City, Kafer Al-Sheikh Governorate. Fish stocked at a sex ratio of 1 male : 2 females. On the first season (year 2000) fish stock was 6000 females $(150 \pm 11.79 \mathrm{~g})$ and 3000 males $(200 \pm 20.41$ 
g). On the second season (year 2001) 7000 females $(65 \pm 3.33 \mathrm{~g}$ ) and 3500 males $(75 \pm 3.33 \mathrm{~g}$ ) and on the third season (year 2002) 8000 females $(112.4 \pm 14.25 \mathrm{~g})$ and 4000 males $\left(132.4 \pm 14.25^{\circ} \mathrm{g}\right)$ were randomly assigned to 10 earthen ponds. The water depth was maintained at about $50 \mathrm{~cm} 10 \%$ of Water was changed every third day. The experiment lasted 6 months during the spawning season from March to September.

Fish were exposed to air temperature naturally from $20.04^{\circ} \mathrm{C}$ to $36.06^{\circ} \mathrm{C}$ in earthen ponds and fed on diets $25 \%$ protein twice daily at a rate of $2.5 \%$ body weight/day. 10 earthen ponds had the same ecological conditions of water were used : -

\begin{tabular}{|l|l|l|}
\hline Oxygen $(\mathrm{ppm})$ & Alkalinity $\mathrm{mg}\left(\mathrm{CaCO}_{3}\right) / \mathrm{L}$ & $\mathrm{NH}_{4} \mathrm{mg} / \mathrm{L}$ \\
\hline $10.56 \pm 1.54$ & $365.5 \pm 18.5$ & $0.075 \pm 0.006$ \\
\hline
\end{tabular}

Female broodstock were checked for spawning after 14 day from stocking by using net mesh pore $1 \mathrm{~mm}$ at the edge of the pond in the morning. After about 21 days, fries are collected and are numbering in nursery net enclosures (hapas); usually made of plastic mosquito netting (mesh pore $1 \mathrm{~mm}$ ). Hapas are very easy to manage; because fry cannot escape harvesting. Hapas sizes are from 1-2 $\mathrm{m}^{2}$ with a depth of 1-2 m, suspended on concert pond.

Transfer the fish broodstock to the same pond. Relative fecundity were calculated in relation to total number of fries per gram body weight of females present in that pond and the spawning percent were calculated in relation to total number of fries in one spawn per total number of fries in season $\times 100$.

\section{II- Statistical analysis:}

Statistical analysis was performed using the analysis of variance (ANOVA) and Duncan's Multiple Range Test (Duncan, 1955). SAS program was used for statistically analysis according to Snedecor (1971).

\section{RESULTS AND DISCUSSION}

A suitable temperature and controlled photoperiod permit a reasonably close prediction of ovulation time. Tilapia do not respond well to hormonal induction to spawning but can be induced to spawn through manipulation of environmental variables (Shelton, 1989). Also, El-Naggar et al. (2000) reported that Nile tilapia (Orochromis niloticus) did not lay eggs when water temperature decreased below 


\section{REPRODUCTIVE PERFORMANCE OF OREOCHROMIS NILOTICUS IN EARTHEN PONDS}

$19{ }^{\circ} \mathrm{C}$. In our study, Nile tilapia (Oreochromis niloticus) begin to give fries at water temperature $20.04{ }^{\circ} \mathrm{C}$ (Tables $3 \& 5$ ). This agrees with Hughes and Behrends (1983) who observed that in spawning of Orochromis niloticus minimum seed production was relatively at low temperatures $24{ }^{\circ} \mathrm{C}$ followed by a marked increase with a sudden rise in water temperatures, reaching a high of $31{ }^{\circ} \mathrm{C}$.

The reproduction activity of Tilapia begins at $22^{\circ} \mathrm{C}$. and the optimal temperature range is $25-29^{\circ} \mathrm{C}$ (Strmuel and Yoel, 1975). In the present work, the reproduction activity of Nile tilapia (Oreochromis niloticus) was maximum at the optimal temperature range 25.06 $31.65{ }^{\circ} \mathrm{C}$. female gave maximum number of fries per day were $7.85 \pm$ $1.73 ; 6.84 \pm 1.16 \& 7.85 \pm 2.03$ fries respectively, in May from the three season (years 2000, $2001 \& 2002$ ) as shown in Table 4. This agrees with Shaikh and Hafeez (1993) who revealed that long photoperiod-warm temperature accelerated gametogenic progress in the prespawning season. Short photoperiod-warm temperature had inhibitory or regression effect in most seasons. Warm temperature in the spawning season, stimulated spawning and low temperature inhibited it regardless of photoperiod. Low temperature in long and short photoperiod initiated gonadal recrudescence in both sexes on Cyprinid fish. Cyprinion watsoni.

El-Naggar et al. (2000) reported that spawning percentage for Oreochromis niloticus averaged 10 and $34 \%$ for natural photoperiod treatments when water temperature increased to $19-21^{\circ} \mathrm{C}$. The most reproductive period coincided with a rise in water temperature from 22 to $27^{\circ} \mathrm{C}$.

In our study, spawning percentage increased during April, May and June $(23.82 ; 30.85 \& 20.61 \%)$ more than other months (Table 5 and Fig 6) and the females gave the highest fries (184.6 \pm 53.01 ; $149.26 \pm 31.87 \& 143.26 \pm 25.37$ fries $/$ month) at average water temperature $20.04 ; 34.75 \& 26.26 "$ " ' respectively, in the three season, as shown in Table 4 and Fig 5. This result agree with Shmuel and Yoel (1975) reported that spawning of Oreochromis niloticus and Oreochromis aureaus begins at $22^{\circ} \mathrm{C}$, and the optimal temperature range is $25-29^{\circ} \mathrm{C}$. In this temperature range, spawning can be easily accomplished throughout the whole year. Similarly, soon after the females complete the incubation and nursing of the young fry they are ready for a new round of mating and highest production of fries in earthen ponds (pure and crossbred fry) during April and May in shallow ponds stocked with one male to every five females. 
Size often plays an important role in reaching sexual maturity and reproductive success. Often the fastest growing individuals within a population will reach sexual maturity the earliest (Dunham, 1990). Sex determination in fish is a very flexible process with respect to evolutionary patterns observed among genera and families, and within individuals is subject to modification by external factors. These influences can affect the fate of both somatic and germ cells within the primordial gonad, and include the action of genetic, envirommental (e.g. temperature), behavioural, and physiological factors (Devlin and Nagahama 2002).

In this study, it was observed that female body weight play an important role in the biginning of spawning. Females with hightest body weight $(150 \pm 11.79 \mathrm{~g})$ gave highest fries number throught April. Seeds recovered during the first harvest through April (109.35 \pm 28.5 total fries $\times 10^{3}$ ) in the first season (year 2000) as shown in Tables 1 \& 3 and Fig. 1. Females with low body weight $(65 \pm 3.33 \mathrm{~g})$ gave more total fries throught June. Seed production gradually increased through June $\left(99.95 \pm 22.56\right.$ fries $\times 10^{3}$ ) in the second season (year 2001) as shown in Tables $1 \& 3$ and Fig. 2 when all females reached maximum seed production. This fourth spawning coincided with a rise in water temperatures, reaching $34.75^{\circ} \mathrm{C}$. While, females with the intermediate body weight $(112.4 \pm 14.25 \mathrm{~g})$ gave more total fries throught May. Seeds were recovered during the first harvest $(115.37 \pm 20.76$ fries $\mathrm{x} 10^{3}$ ) in the third season (year 2002) as shown in Tables 1 \& 3 and Fig. 3. This result agrees with Shmuel and Yoel (1975) who reported that spawning of Tilapia family and sexual maturity when the fish are 4-6 months old, and reach a body weight 50-100g. Athough Abd ElNasser and El-Ghobashy (2000) reported that the bigger sizes of Clarias gariepinus in the wild start to spawn first before the intermediate sizes then comes the turn of the smaller ones at the end of the spawning season.

Hughes and Behrends (1983) reported that the highest total seed production from Oreochromis niloticus differed with respect to age and mean weight of females. The highest total seed were found in treatments characterized by the lower stocking density $(5 / \mathrm{m} 2)$ and lower sex ratio (1:2), , while low or intermediate levels of seed production were found for either the $1: 2$ or $1: 3$ sex ratio in combination with the $10 / \mathrm{m} 2$ stocking density. Siraj ef al. (1983) reported that low fecundity of female Oroechromis niloticus $(44 \mathrm{~g}$.) range of from as low as 580 eggs per clutch per year and females (280 


\section{REPRODUCTIVE PERFORMANCE OF OREOCHROMIS NILOTICUS IN EARTHEN PONDS}

g.) to as high as 1820 eggs per clutch per year. In our study, the highest relative fecundity increased with the decreased female body weight. Female with low body weight $(80.71 \pm 16.06 \mathrm{~g})$ has more relative fecundity $(1.76 \pm 0.24 \mathrm{fries} / \mathrm{g}$ body weight) as shown in Tables $1 \& 5$ and Fig. 4. On the other hand, female with high body weight $(150 \pm 11.79 \mathrm{~g})$ has small relative fecundity $(1.25 \pm 0.41$ fries $/ \mathrm{g}$ body weight) as shown in Tables $1 \& 5$ and Fig. 4. Also. females with intermediate body weight $(112.4 \pm 14.25 \mathrm{~g})$ have intermediate relative fecundity ( $1.30 \pm 0.34$ fries/g body weight) as shown in Tables 1 \& 5 and Fig. 4. This result agrees with Silvera (1978) who found that seed production of Oreochromis niloticus was reduced significantly when brood fish density reached $8 \mathrm{fish} / \mathrm{m}^{2}$ at a total female weight of 526 $\mathrm{g} / \mathrm{m}^{2}$. Also. Hussein and Farag (2002) found that relative fecundity to Oroechromis niloticus in hapa ranged from 2.29 to 3.62 fries $/ \mathrm{g}$ female body weight through spawning season.

Huang and Gall (1990) stated that the genetic correlations between body weight and egg production traits in channel catfish, especially body weight at early stages of development. They found no genetic relationship of fry weight with female post-spawning weight. In our study, fries production per spawn were 184.6 53.01 ; $149.26 \pm 31.87$ and $143.26 \pm 25.37$ fries / female, when water temperature was $20.04: 26.79$ and $26.26^{\circ} \mathrm{C}$. respectivialy as shown in Table 4 and Fig 5. That is to say, fries production per spawn per female did not vary among treatments for all levels of water temperature or the small change in number of females in the three seasons, but depend on female body weight, which may suggest that water temperature affects merely spawning frequency but not the volume of fries production per spawn. These results agree with $\mathrm{Su}$ et al. (1996) who reported that reproductive efficiency is another economically important trait, especially for trout breeders producing fertilized eggs or fingerlings. Consequently, the genetic correlations among body weight and reproductive traits have an important implication to the design of breeding programs to enhance the overall net value of a stock. El-Naggar et al. (2000) stated that egg production per spawn per female did not vary among treatments for all levels of crude protein, photoperiod and water temperature, which may suggest that photoperiod affects merely spawning frequency but not the volume of egg production per spawn.

Results show that the reporoductive performance of Oroechromis niloticus could be maximized by holding broodstock 
under natural photoperiod in water temperature above $20^{\circ} \mathrm{C}$, the optimal reporoductive performance occures through summer season during April, May and June. The optimal water temperature range from 28 to $31{ }^{\circ} \mathrm{C}$, females with the highest body weight started to spawn first and gave more total fries before the intermediate body weight and water temperature affected merely spawning frequency. but not the volume of fries production per spawn.

\section{REFERENCES}

Abd El-Nasser, G. and Elghobashy, H. (2000). An assessment of the reproductive performance of wild and captive Clarias gariepinus. Annals of Agric. Sc., Moshtohor., 38 (1): 93-100.

Abd El-Nasser, G. ; Shokr, E. and Abdel-Hakim N. F. (2001). Manipulation the spawning time of the african catfish (C/arias gariepinus) using temperature and photoperiod. Egypt. J. Aquat. Bio. \& Fish., 5 (4): 11-28.

Badawy, E. A. (1993). Biological studies on Tilapia species as a major component of the Egyptian fish farming system. Ph. D. Thesis, Faculty of Science. Zagazig University. $222 \mathrm{pp}$.

Carriillo, M. ; Zanuy. S. ; Part. F. ; Serrano, R. and Bromage. N. (1993). Envirommental and hormonal conirol of reproduction in sea bass. In "Recent Advances in Aquacult.". IV Ed. Muir, J. \& Roberts.R.

Dagzie, M. (1982). Species combination in Tilapia culture. Aquacult.. 27: 295-299.

Devlin, R. H. and Nagahama, Y. (2002). Sex determination and sex differentiation in fish: an overview of genetic. physiological. and envirommental influences. Aquacult., 208 (3-4) 191-364.

Duncan, D. B. (1955). Multiple ranges and multiple F-Tes1. Biometric, $11: 1-42$. 


\section{REPRODUCTIVE PERFORMANCE OF OREOCHROMIS NILOTICUS IN EARTHEN PONDS

Dunham, R. A. (1990). Production and use of monosex or sterile fish in aquacult. Rev. Aquat. Sci., 2: 1-17.

El-Naggar, G. O. ; El-Nady, M. A. ; Kamar, M. G. and Al-Kobaby, A. I. (2000). Effect of photoperiod, dietary protein and temperature on reproduction in Nile tilapia (Oreochromis niloticus). In the $21^{\text {st }}$ Century Proceedings from the Fifth International Symposium on Tilapia Aquaculture. Hotel Sofitel Rio Palace Convention Center Rio Die Janeiro-RJ, Brazil September 3-7, 2000, 352-358 pp.

El-Saby, M. K. (1951). The lake fisheries of Egypt. Proc. Un. Sci. Conf. Conserv. Unil. Resource. 7: 126-130.

Gonzalez, C. E. (1997). "La Piscicultura en Colombia: Technologia de Punta en El Departamento del Valle del Cauca". Pp. 7884 in D. E. Alston, B. W. Green and H. C. Clifford. editors. IV symposium on aquaculture in Central America: focusing on shrimp and tilapia, 22-24 April 1997. Tegucigalpa, Honduras. Asociacion Nacional de Acuicultores de Honduras and the Latin American Chapter of the World Aquacult. Society.

Huang, N. and Gall. G. A. E. (1990). Correlation of body weight and reproductive characteristics in rainbow trout. Aquacult., 86 . $191-200$.

Hughes, D. G. and Behrends, L. L. (1983). Mass production of Tilapia nilotica seed in suspended net enclosures. International symposium on Tilapia in Aquaculture. Proceedings Nazareth Israel May 8-13, 1983. 394-401 pp.

Hussein Attia Elghobashy and Mohamed El- Sayed Farag (2002). Evaluation of growth performances crosses for different populations of Nile tilapia (Oreochromis niloticus). $1^{\text {st }}$ Scientific Conference of the Egyptian Aqriculture Society Faculty of Enironmental Aqricultural Sciences El-Arish. North Sinai, Egypt. 13-15 December, 2002. 
Lovshin, L. L. (1997). "Worldwide Tilapia Culture". in Anais do I Workshop International de Aquicultura, October 15-17. 1997, 96-116 pp. Sao Paulo, Brazil.

Myers J. M. ; Penman, D. J. ; Basavaraju, Y. ; Powell, S. F. ; Baoprasertkul, P. ; Rana, K. J. ; Bromage, N. and McAndrew, B. J. (1995). Induction of diploid androgenetic and mitotic gynogenetic Nile tilapia (Oreochromis niloricus: L.). Theor. Appl. Genet.. 90: 205-210.

Rana, K. J. (1988). Reproductive biology and the hatchery rearing of tilapia eggs and fry. In: J. F. Muir and R. J. Roberts (Editors), Recent Advances in Aquaculture, 3. Croom Helm, London, 343-406.

Shaikh, S. A. and Hafeez, M. A. (1993). Effects of photoperiod and temperature on gonadal response in the cyprinid fish, Cyprinion watsoni. PAK. J. Zool., 25 (3): 233-24.

Shelton, W. L. (1989). Management of finfish reproduction for aquaculture. CRC Rev.Aquat. Sci., 1:497-535.

Shmuel R. and Yoel P. (1975). Induced spawning and africial incubation of Tilapia. Aquacult., 5: 315-321.

Silvera, P. A. W. (1978). Factors affecting fry production in Sarotherodon niloticus (Linnaeus). M.S. Thesis. Auburn University, Alabama, USA, 40 pp.

Siraj, S. ; Smitherman. R. O. ; Castillo-Gallusser, S. and Dunham. R. A. (1983). Reproductive traits for three year classes of Tilapia niloricus and maternal effects of their progeny. In. Fishelson, L. and Yaron, Z. (compiliers). International Symposium on Tilapia in aquaculture. Tel Aviv Univ.. 210$218 \mathrm{pp}$.

Smith, E. S. (1996). "Factors Affecting Sex Reversal of Tilapia: Species Characteristics and Feed Storage Conditions". M. S. Thesis, Department of Fisheries and Allied Aquacultures, Auburn University, Alabama 36849, USA. 


\section{OF OREOCHROMIS NILOTICUS IN EARTHEN PONDS}

Snedecor, G. W. (1971). "Statistical Methods" $14^{\text {th }}$. Ed. Imes. Iwa. The lowa State Univ. Press, 593 pp.

Su, G. S. ; Liljedahl, L. E. and Gall, G. A. E. (1996). Genetic and environmental variation of body weight in rainbow trout. Aquacult., $1+3: 71-80$.

Su, G. S. ; Liljedahl, L. E. and Graham, A. E. Gall (2002). Genetic correlations between body weight at different ages and with reproductive traits in rainbew trout. Aquacult., $2 / 3(1-4): 85-$ 94.

Yeheskel, O. and Avtalion, R. R. (1986). Artificial fertilization of Tilapia eggs. a preliminary study. In: Reproduction in FishBasic and Applied Aspects in Endocrinology and Genetics. Les Colloques de l'INRA no. 44, Institut National de la Recherche Agronomique, Paris, 169-175 pp. 


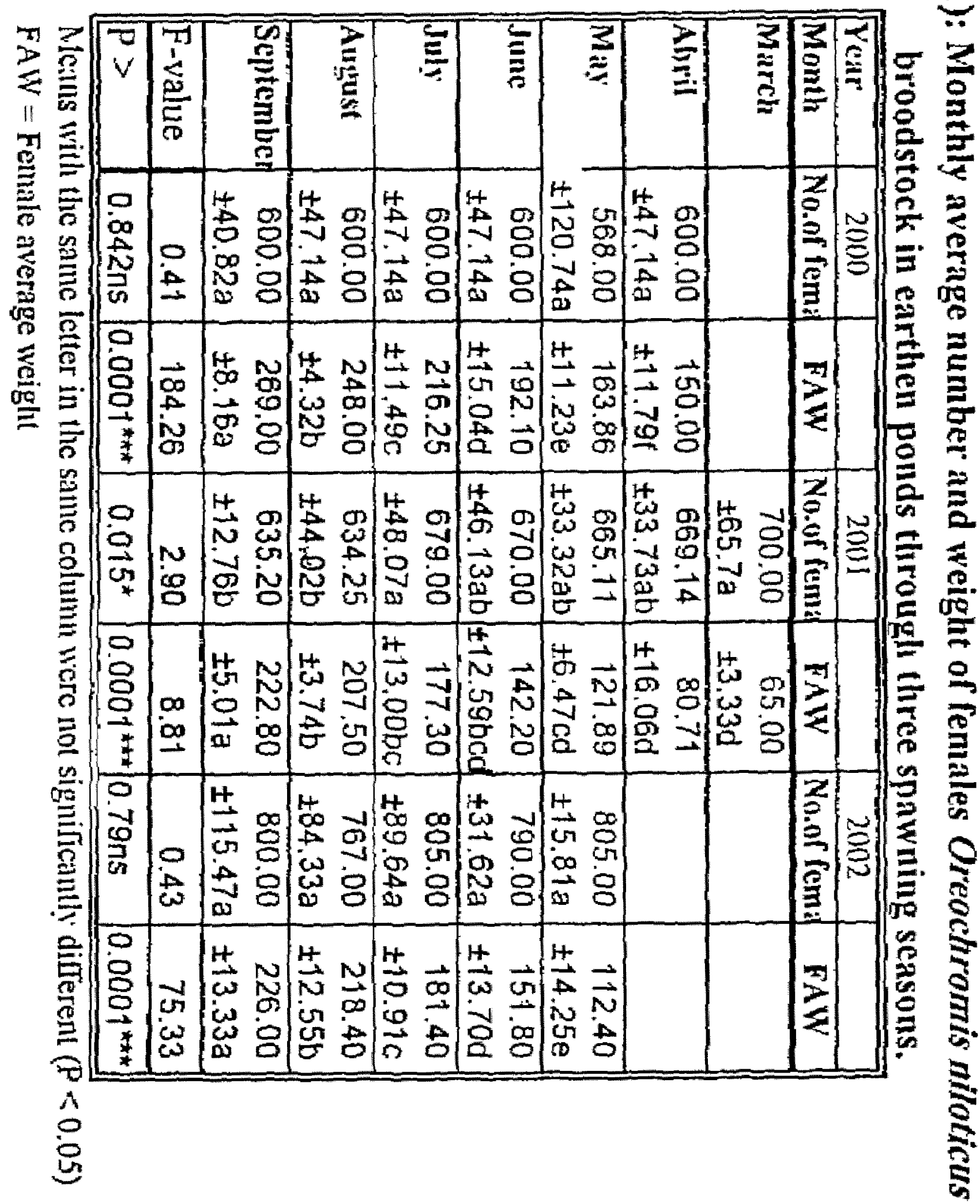




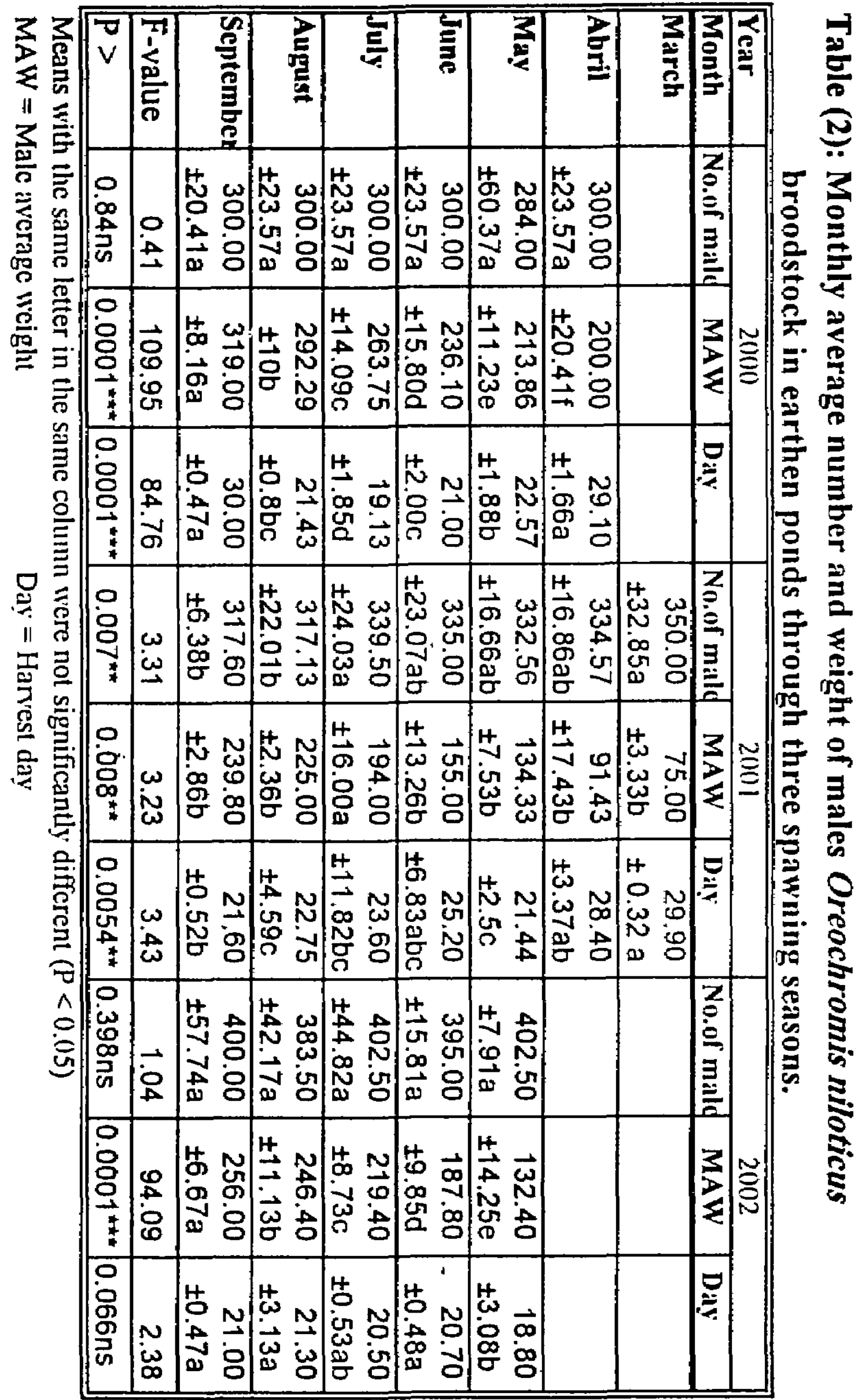




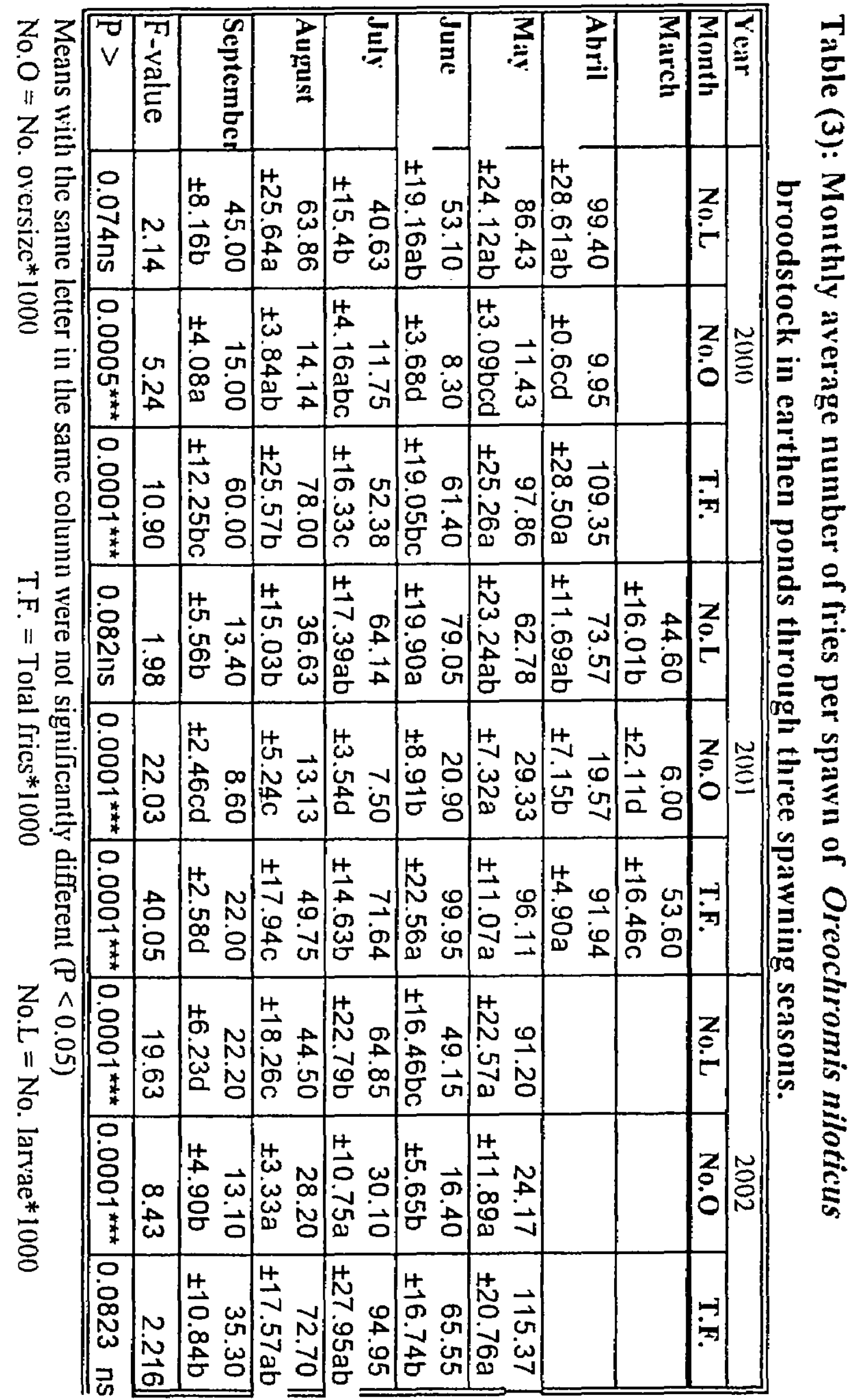




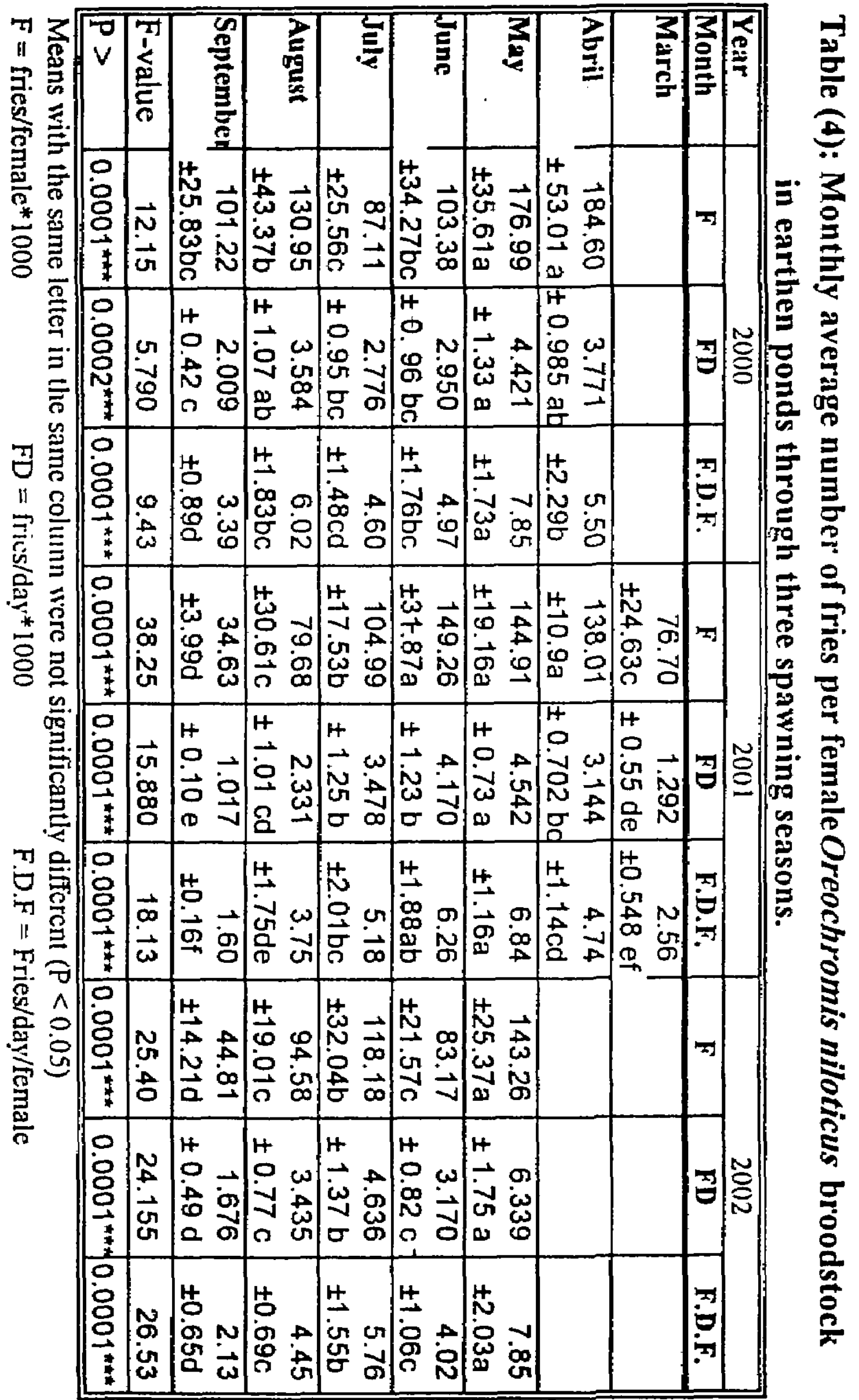




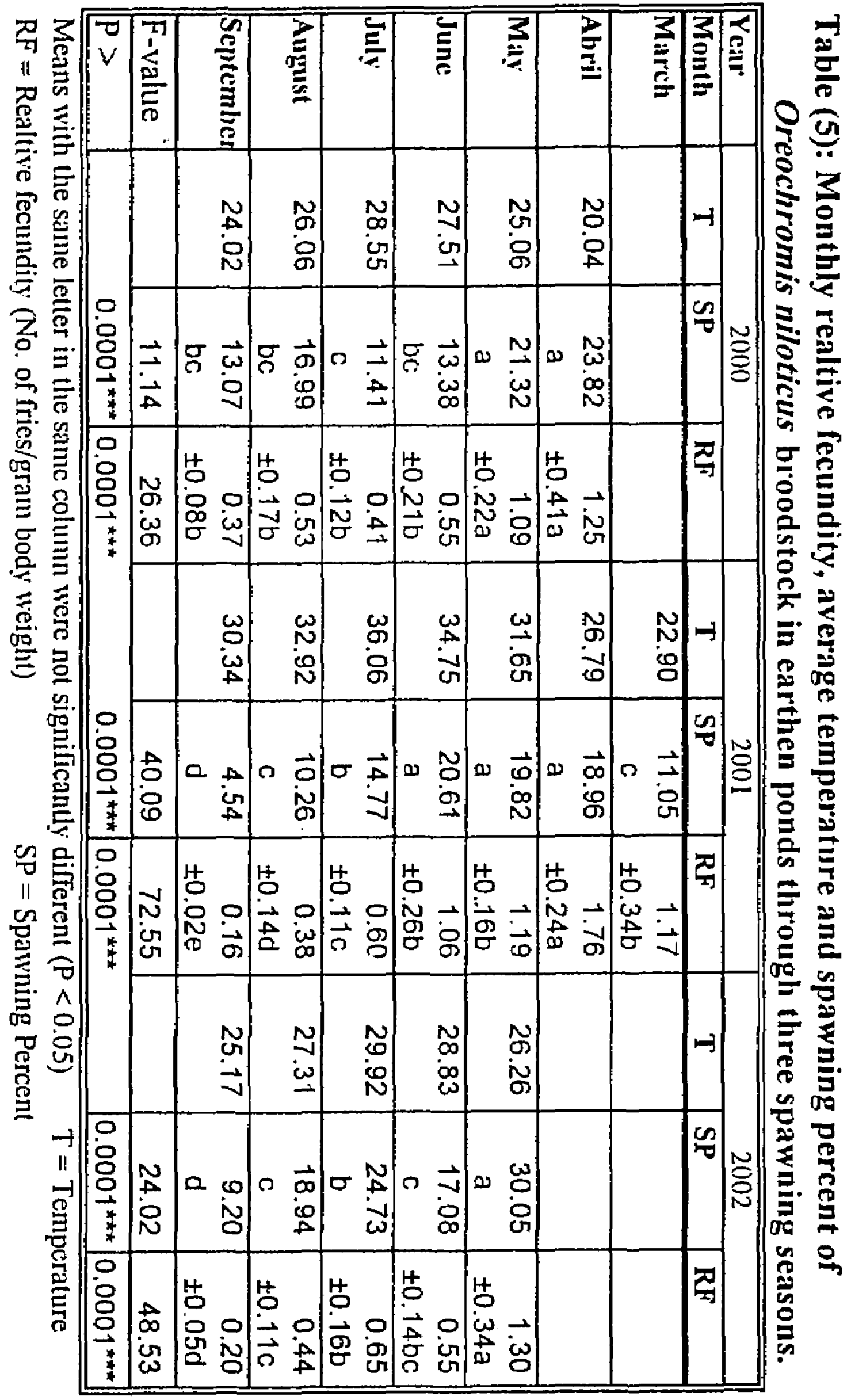




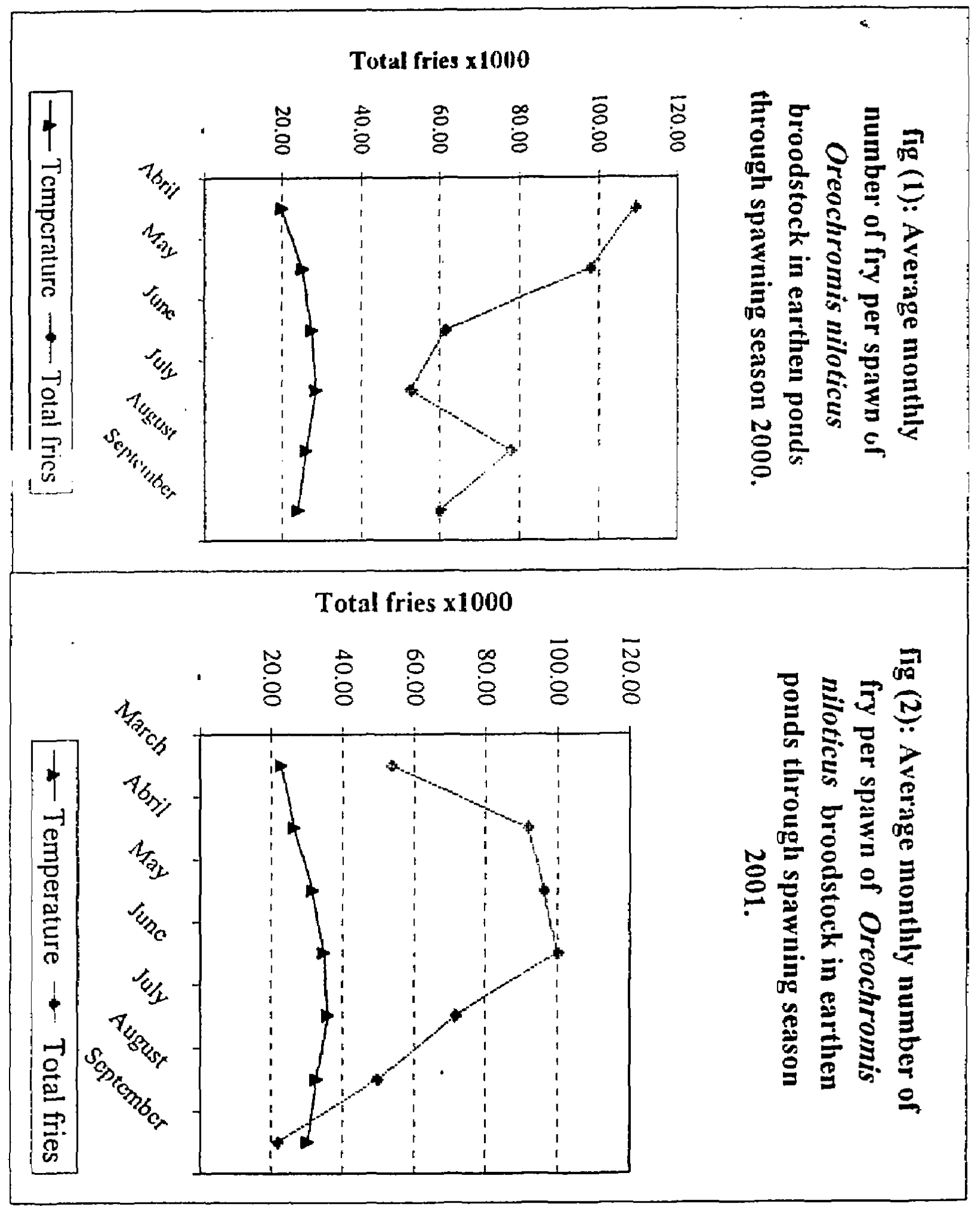




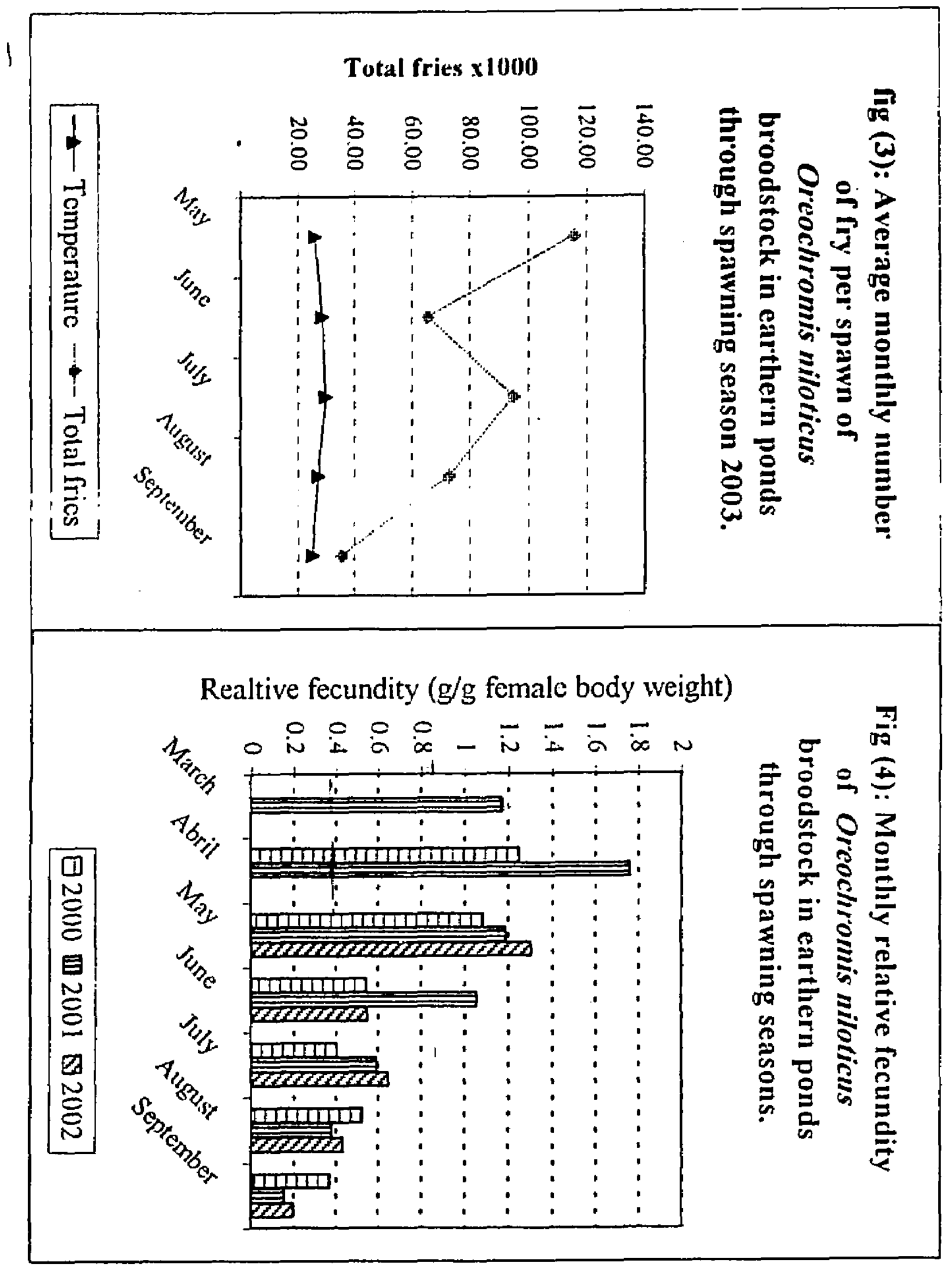




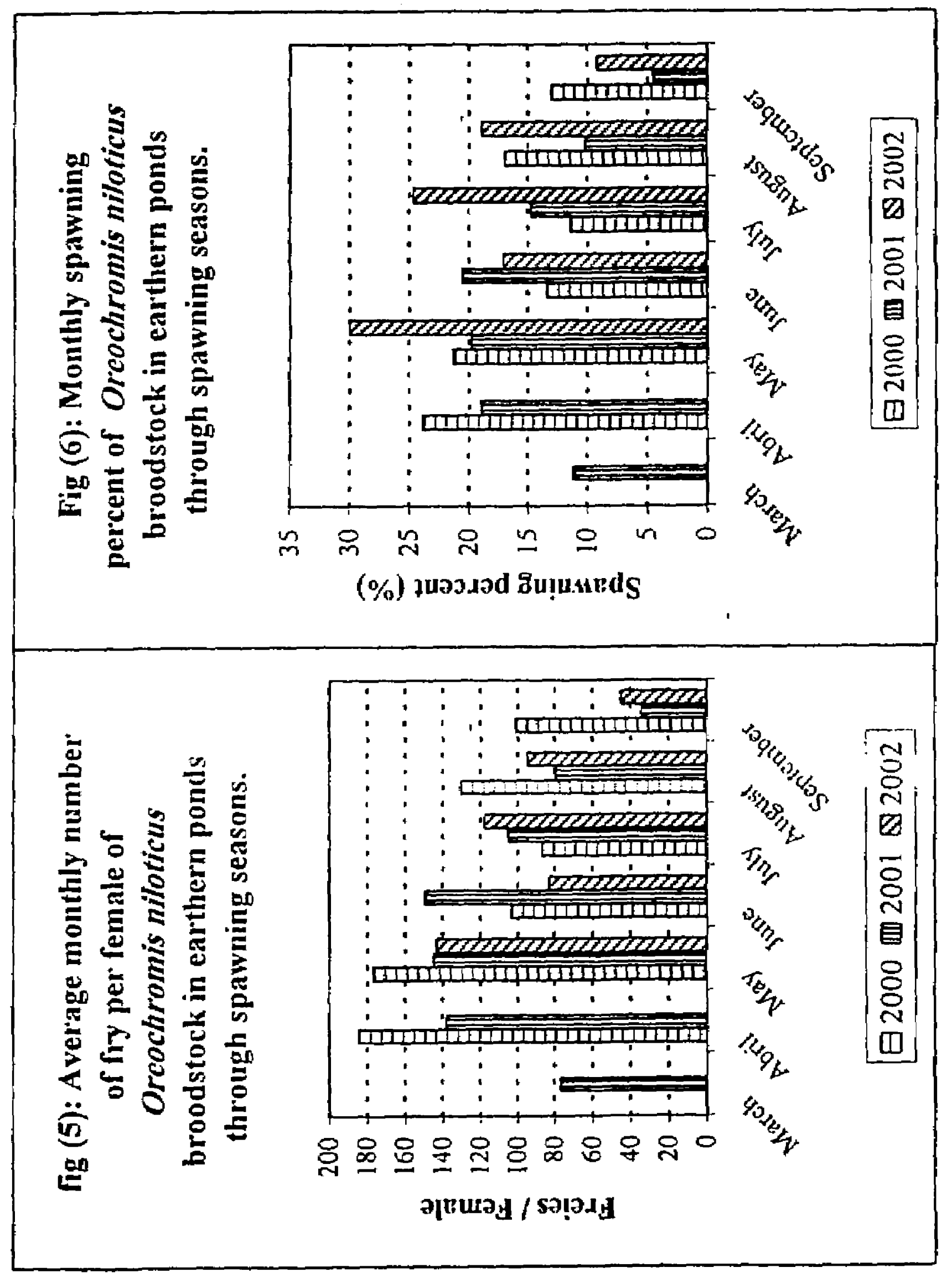

